$A-R\left[\begin{array}{c}\text { Eberts } \\ T . S i\end{array}\right]$ 1907 
HARVARD UNIVERSITY.

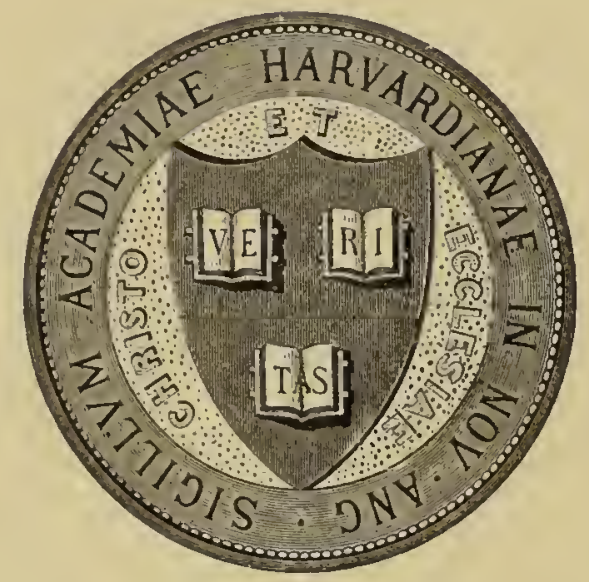

LIBRARY

OF THE

MUSEUM OF COMPARATIVE ZOÖLOGY 54,039

BEquesT OF

WILLIAM BREWSTER

17 ay 1,1920. 


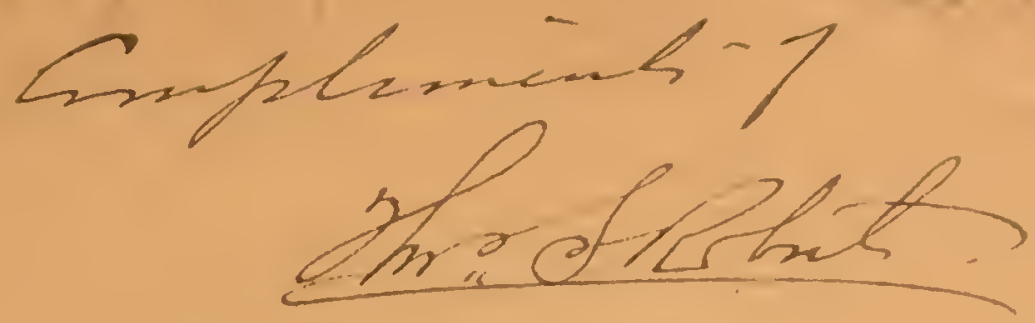





\title{
LIST OF BIRDS OF BECKER COUNTY, MINNESOTA.
}

\author{
Compiled by Thos. S. Roberts, M. D.
}

DIRECTOR DEPARTMENT OF BIRDS, MINN. NAT. HIST. SURVIY.

\section{From}

A Pioneer History | of | Becker County | Minnesota | including | a brief | Account of its Natural History | as embraced in the Mineral, Vegetable and Animal | Kingdoms, and a History of the early Settlement | of the County; also, including a large Amount of | valuable Historical Information collected by $|-|$ Mrs. Jessie C. West. $|-|$ and numerous Articles written by various early | Pioneers relating to the History of | the Several Townships of | Becker County $|-|$ By Alvin H. Wilcox -| Pioneer Press Company | St. Paul, Minn | 1907 Large 8vo., pages 757, many illustrations.

This list of birds was hastily prepared on short notice for Mr. Wilcox's "History of Becker County" and is incomplete in many particulars. It was intended chiefly for popular perusal, and to indicate to the residents of Becker Co. about how many and what birds might be looked for in their vicinity. Becker County lies in tle southern part of the northwestern onefourth of the State. It is a rectangle 48 miles east and west by 30 miles north and south. The southern boundary line lies just below $46^{\circ} 15^{\prime}$ north latitude and the $96 t_{1}$ meridian passes but a few miles east of the western boundary line. 



\section{Chapter VIII.}

\section{LIST OF BIRDS OF BECKER COUNTY, IMINNESOTA.}

Conplatio m Thos. S. Romerts, M. D.

DIRECTOR DEPARTAFNT OF BIRDS, MINA. NAT, HIST. SURVEY.

Becker County, lying as it does between the great forest region of northwestern Minnesota and the trecless plains to the westward, is ideally situated for presenting within its boundaries a great varicty of bird life. The western one-third of the connty is rolling prairie, sloping from elevations of $\mathrm{I} 400$ to 1500 fect along the forest border, toward the Red River Valley in the tier of counties adjoining it on the west. This, with several isolated areas of prairie in the forests farther east, provides congenial homes for a large number of prairic loving birds. Among these are a few species belonging more appropriately to the high Cotcan regions of North Dakota, as, for example, the Lark Bunting, Sprague's Pipit. Chestnut-colored Longspur, Burrowing Owl and several others. The remaining two-thirds of the county are more or less thickly covered with forest. Pine trees, spruces and fir balsams are found throughout much of this area. Deciduous trees of many species are abundant or predominate in the southern and central portions of the county, but in the northeastern quarter the forest becomes more distinctly coniferous and both the fauna and the flora present the typical Canadian aspect. Thus there is presenter in the timbered regions of the county a diversity of conditions which attracts almost all the avian forest dwellers of the state.

The prairics and forests of Becker County are diversified by over 88.000 acres of water in the form of lakes and ponds and many streams. Thus an immense number of aquatic bircls here find congenial surroundings and ample opportunity to disport themselves, feed and raise their young. With the advent of man and the inevitable and largely unavoidable destruction of primitive conditions, there has been a widespread and wholesale diminution in the numbers of the water birds, extending in some instances to almost the entire disappearance of species once conspicuous features of the bird life. Some of these birds, as the swans, geese, pelicans, curlews, avocet and gorwits cannot live in the wild state in associa- 
tion with civilized conditions any more than could the buffalo, antelope or elk, and there is no hope that they will ever again be restored to the old places where they were once so abundant. A few have left their names attached to lakes and rivers, as empty reminders of their early occupancy of the land.

The following list of bircls of Becker County has been compiled from information in the possession of the Minn. Nat. Hist. Survey derived from several sources. In the early eighties Prof. W. W. Cook, now connected with the Biological Survey, Washington, D. C., was stationed at White Earth Agency and collected much information in regard to the bird life of that locality, which has found its way into print in several connections, particularly in his well known "Nigration of Birds in the Mississippi Valley." In I883, Mr. Foster H. Brackett, of Massachusetts, who died a few years ago, prepared an annotated list of birds observed about Detroit in the month of May of that year. This list was published in the Quarterly Journal of the Boston Zoological Society, Vol. II, r883. The writer spent nine weeks in the summer of I902 studying the birds of the Lake Itasca region, immediately adjoining the northeastern corner of Becker County, and the information there obtained applies equally well to the evergreen forests of the county under consideration. The data from these three sources have been used, supplemented by safe inferences from what is known of the general distribution of our birds. In this manner a list has been prepared which will, it is hoped, give to the general reader a fair idea of the bird life of Becker Connty. To the bird student, who may have opportunity to give close attention to the subject it will at least provide a basis for future more exact annotation.

Total number of species of birds occurring in Becker Count .262 Water birds occurring in Recker County............... $8_{3}$ Land Birds occurring in Becker County............. iz9 Stmmer Residents (Breeding birds) ............... I58

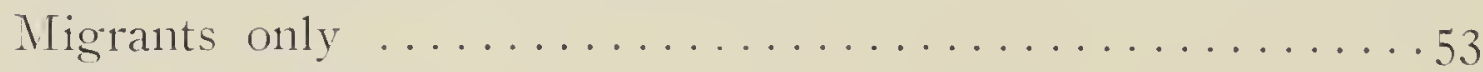

Winter Visitants ....................... I

Permanent Residents ...................... 8

Accidental ...........................

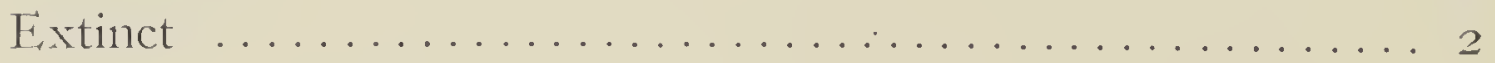


I. Westerre CiRlib: (Acchmophom occidentalis.)

A western species, probably occurring occasionally in the lakes and marshes.

2. Hordonimis Grebr, Red-necked (irede (Colymbus holbollii) Undoubtedly breeds in colonies in the marshy bays of the larger lakes, as it does in Crant County and at Leech Lake.

3. Horneid Gribi: (Colymbus auritus).

To be looked for chiefly spring and fall in open water.

4. EARE:D GREBE: (Colymbus nigricollis californicus).

A western species, breeding in colonics in marshes and sloughs.

5. Pilid-Bill,fid Grebe, Dabchick, "Hell-diver" (Podilymbus podiceps).

The common species of grebe, breeding abundantly in all shallow lakes and sloughs. The grebes all construct floating nests of water-soaked, decayed vegetation, depositing the oval-shaped, much stained eggs in a shallow depression in the top. In the absence of the parent bird the eggs are covered with wet material and it is generally thought that incubation is partly accomplished by the action of the sun upon this mass of damp vegetation.

6. Loon, Great Northern Diver (Urinator imber),

A common and well-known bird. The two large olivegray, black-spotted eggs are usually deposited in a depression on an old muskrat house on the edge of open water.

The Black-throated and Recl-throated Loons, high northern specics, may occasionally occur in early spring and late fall.

7. Herring Guli, (Larus argentatus).

This is the large white gull commonly seen spring and fall, flying over the larger lakes. It breeds farther north.

8. Ring-BitheED Gul, (Larus delawarchsis.)

A smaller gull similar to the last.

9. Franklin's Guli, (Larus franklinii).

The only gull found during the summer months. It breeds in colonies in sloughs and marshy lakes. The farmers call it the "Prairic Dove" and it may often be seen fol- 
lowing the "breaking ploughs," picking up the grubs and worms as they are turned up by the plough-share.

io. Bunapartés Guld (Larus pliladelphia).

Similar to the last in size and general appearance. A nigrant, spring and fall, breeding in the far north. Often seen in great flocks late in the fall.

i I. Caspian Tern (Stcrna caspia).

To be looked for as an uncommon migrant.

I2. FORS'TER'S TERN (Stcrna forstcri).

A summer species, breeding in the sloughs and marshy ponds in company with Black Terns. This bird with its black cap, pearl gray mantle, long forked tail, and snowy white under parts, well merits the name of "Sea Swallow," sometimes applied to the Terns.

The Common and I east Terns may occasionally occur but are imperfectly known as Minnesota birds.

I3. BrACK TrRN (Hydrocluclidon nigra surinamcnsis).

An abundant and, in the breeding season, noisy bird, nesting everywhere in sloughs and wet marshes. It constructs a rather neat but frail nest of fine stems on floating vegetation and lays from two to four dark, spotted, strongly pyriform eggs, similar in appearance to those of most Terns. The black body-plumage of the adult bird renders it very unlike its snow-white relatives, in appearance.

I4. DOUnLE-CRESTED CORMORANT, "Black Loon" (Plalacrocorar diloplutus).

A common bird, congregating in certain localities where they build their nests in the tops of trees or on the ground, usually on islands in large lakes. It has rapidly decreased in numbers of late years. Cormorant Lake in the southwestern part of the County derived its name from the presence in former years of a colony of these birds.

I5. WhiTe PEI,ICAN (Pclccanus crythrorlynchos).

This large bird,-formerly abundant, nesting on the ground in colonies, - is now greatly reduced in numbers, occurring chiefly in small wandering companies.

i6. AmElicAN MERGANSER, Sheldrake, (Merganser americamus). Probably appears chiefly as a migrant spring and fall. 
17. RED-bREASTEL MERGansiar (Merganser serrator).

May be looked for as a breeding bircl as well as migrant. Nest on ground near water.

I8. Hoodid) Mlikciansirr, "Fish Duck," "Saw-bill," (Lophodytes cucullatus).

A connmon duck, nesting in hollow trees. Renains late in the fall, often in rapid places in streans, when all still water is frozen over. A beatiful bircl but the flesh usually "fishy" and indifferent eating.

19. Maliakd, "Green-head" (Anas boschas).

Breeding commonly in marshes and sloughs, especially in the prairie portions of the county. This, like all the ducks, has been reduced deplorably in numbers of late years. Still an abundant migrant spring and fall.

'The Black Mallard, or Dusky Duck, probably occurs sparingly during migrations.

20. Cudwali, Gray Duck (Chaulelasmus streperus).

Common, breerling; similar to Mallard in its summer habits.

zг. B.h.dplte, American Widgeon (Mareca americana).

Not very common, breeds.

22. Green-winged Teal (Nettion carolinensis).

Common spring and fall, but for the most part breeding further north.

23. Br,ue-WINGed T'TAL (Querquedula discors).

An abunclant bird in all suitable localities, nesting commonly about marshes and ponds.

The western Cinnamon Teal may occur occasionally as a rare straggler.

24. SHoNkit,ER, Spoon-bill (Spatula clypeata.)

Common, breeds. Usually light in weight and a poor duck for the table.

25. Pixtan, "Sprig-tail" (Dafila acuta).

A common early spring and fall migrant, appearing in large flocks; breeding less numerously in the prairie portion of the Connty.

26. Woon Duck (tir sponsa).

'This gorgeously colored and valuable duck is rapidly decreasing in numbers everywhere with the advent of civilization. The Wood Duck, as its nance implies, is partial 
to the streams and ponds of woodlands. It builds its nest in a cavity in a trec, often at a considerable distance from water.

27. REDHisd (Aythya ancricana).

Common, breeding in the sloughs and around the edges of marshy lakes in the more open portions of the county.

28. Canvas-back (Aythya iallisucria).

A less common breeder, but numerous spring and fall. This and the last species are fond of the wild celery and congregate in the fall in great flocks on lakes where this plant is abundant.

29. Griater Scaup Duck, Large Blue-bill (Aythya marila).

Found spring and fall, but less commonly than the next species.

3o. Lesserr Scaup Duck, Blue-bill (Aythy'a affinis).

Abundant spring and fall, furnishing a considerable part of the late pass-shooting. Breeding sparingly about marshy lakes.

31. RinG-NeCKED DUCK, "Black Duck" (Aythya collaris).

A common and valuable duck, breeding in the marshes and appearing as a migrant in great numbers spring and fall. In size and appearance very like the Lesser Scaup, but the wing patch, or speculum, is bluish gray instead of white as in the Scaup.

32. GOLDEN-EY, Whistle-wing (Clangula clangula americana).

Nowhere common; found chiefly about the larger lakes and along rivers. Nests in a hollow tree.

A northern species, Barrow's Golden-eye, may occasionally occur during winter along rivers where the water flows too rapidly to freeze.

33 Buffitistan, "Butter-ball" (Charitonetta albeola).

Frequent spring and late fall, preferring open water.

May occasionally breed: nests in hollow trees.

34. White-Winged Scoter (Oidemia deglandi).

This and its two congeners, the American and Surf Scoter, are chiefly birds of the sea-coasts and high northern regions, but are occasionally found in the interior and an individual belonging to this group nay now and then be taken spring or fall or even during the winter months 
where there chances to be open water. They are of little or no value as game bircls.

3.5. Rudor Duck (Frismatura jamaicensis).

This curious little duck with its spike-like tail is a common bird in reedy, marshy lakes, and nests commonly about their margins, floating its bulky nest among the rushes and cat-tails. It is an expert diver and generally adopts this method of escape when hard pressed, after the manner of grebes.

36. LESSER SNow Goost: White Brant (Chen hyperborea).

Formerly an abundant species in the prairie regions, appearing from the north in late fall in vast flocks; now, much reduced in numbers.

The Blue Goose (Chon cormlescons) may occur as a straggler during migration.

37. WhITE-FRONTED GoOse (tuser albifrons gambeli).

An arctic-breeling species that may occur rarely during migrations.

38. CANAd Goose. "FTonker" (Branta canadensis).

A common migrant spring and fall and formerly a regular breeder in the prairie regions, but now rarely, if ever, found during the summer.

The Hutchin's Goose and the Cackling Goose, varieties of the Canada Goose, probably occur during the spring and fall migrations. The true Brant (Branta bermicla) is rarely if ever found in Minnesota, despite the many records to the contrary. The Snow Goose is so minersally known among sportsmen by the name of Brant, that it has led to much confusion in statements regarding these birds.

39. Whistina Sivan (Olor colmmbiamms).

40. Trumetek Swan (Olor buccinator).

Of these two species the Whistling Swan breeds in the far north and is only found in Minnesota during migrations and is then an unconmon bird.

The 'Trumpeter Swan formerly bred commonly from Iowa northward, as evidenced by the many bodies of water named after this bird. Now few, if any, remain to breed within our territory. Small parties of the latter species are still to be found, however, during the migratory seasons. 
4T. Americhn BitTerRe (Botaurus lentiginosus).

A common bird of marsh and lake side. Familiarly known by the names of Stake-driver, Shite-poke, Thunderpump, etc.

42. LEAST Bitererin (Ardetta coritis).

This slender, curious little bird is common among the rank growth of the marshes, especially among the quillreeds; but its elusive habits result in its being little known.

43. Greit Blue Héron (Ardea herodias).

A common bird about the shores of lakes and along the banks of streams. Nests in colonies in the tops of tall trees, often in company with Cormorants. This bird is popularly known by the name of "Crane;" but, though it has long legs and a long neck, it belongs to a different family from the Cranes proper.

44. Biací-Crowned NigitT HERON (Nycticorar nycticorar novius).

May possibly occur in Becker County, but the locality is rather far north for this species.

45. Whooping CRANe (Grus americana).

A migrant, spring and fall, now becoming rare.

46. Sandhili, CRAne (Grus Mericana).

Once a very common bird, breeding in the great prairie marshes, but now chiefly a migrant. Usually seen and heard flying high overhead.

47. KING RaIL (Rallus elegans).

Possibly a rare summer resident.

48. Virginia Rair, (Rallus airginiamus).

49. Carolina Rail, Sora (Porsana carolima).

This and the preceeding species are the common Rail birds of the marshes, the Sora, however, far out-numbering the larger and longer-billed Virginia Rail. The Sora remains until the marshes freeze in the Fall, when they disappear in a night as if by magic.

5O. YELlow RaIl, (Porwana nozeboracensis).

Prof. W. W. Cooke has seen this little Rail once at White Earth Agency in the latter part of June, which would indicate it as a breeding bird. On account of the dense marshy growth, which it frequents, and its indisposition to take 
wing when disturbed, it is not easy to observe and may be long overlooked where it is not uncommon.

5I. Coot, Mud-hen (Fiulica americana).

An abundlant and well-known bird, brecting in great numbers in sloughs and marshy lakes.

The Florida Gallinule (Gallinula galcata) may occasionally occur in similar surroundings, though it is naturally a more southern bird. The red bill and frontal shield will distinguish it from the Coot, in which the bill is white with brown shield. The Gallinule, in habits, is more like a Rail than a Coot.

52. Wilson's Pinalarope (Steganopus tricolor).

This gentle, graceful bird is a common summer resident on the prairie meadows. Contrary to the usual custom, the fenlale Phalarope is the gay-colored member of the family. and leaves the incubation of the eggs and care of the young to her plainly-colored mate.

Another species, the Northern Phalarope, probably occurs as a rare migrant.

53. Avoceit (Recurirostra americana).

Formerly a breeding bird throughout the prairie regions of Minnesota, now of rare occurrence.

54. Woodcock (Philohela minor).

Frequents low, wet woodland. Uncommon.

55. Wilson's Snipe. Jack Snipe (Gallinago delicata).

A common bird in meadows and along the marshy borders of lakes and streams, especially in spring and fall, a few nesting in such localities.

56. Long-billed Dowitcher, Red-breasted Snipe (Macroshamphus scolopaceus).

Breeds in the far north; migrates through our state in little flocks, when it is to be found frequenting sloughs or marshes.

57. Strit Sanderlin (Micropalama hymantopus).

A rare migrant.

58. Kxot, Robin Snipe (Tringa canutus).

May occur as a rare migrant.

59. Pectoran, Sandpreer, Jack Snipe ('Tringa maculata).

Usually a common migrant. 
6o. Winte-kumped Sandpiper (Tringa fuscicollis).

A migrant spring and fall.

6r. Balrd's Sandpiper (Tringa bairdii).

Sometimes a common migrant found along the sandy shores of lakes, often in company with the next species.

62. Leas't S.anderier (Tringa mimutilla).

A common bird spring and fall along the shores of lakes and streams. Breeds far north.

63. ReD-backin Sandelikr (Tringa alpina pacifica).

Occasionally found during migration in similar situations as the last two and the next species.

64. Semi-palmated Sandpiper (Eremietes pusillus).

Associates with the Least Sandpiper, which it closely resembles in most ways, but may be distinguished by the webbed base of its toes.

65. Sanderiting (Calidris archaria).

A coast-wise bird, occurring as a rare straggler if at all. Has been taken several times in Minnesota.

66. Marbleid Godwit (Limosa fedoa).

Once an abundant and conspicuous summer resident over all the prairie regions of Minnesota, but now so reduced in numbers as to be almost uncommon.

67. Hudsonian Godwit (Limosa hamastica).

May occasionally be encountered as a migrant.

68. GREATER YELLOW-LEGS (Totanus melanolcucus).

69. LESSER YELLOW-LEGS (Totanus flazipes).

Both these long-legged snipe are common and early migrants and their loud "Tell-tale" cries are well known sounds about mud flats and marshy lake-sides. A few are to be found during the summer months, but they breed almost entirely in the far north.

7o. Solitary Sindpiper (Helodromas solitarius).

A common migrant found chiefly about ponds and streans in wooded regions. A few pass the summer and probably nest in such localities. The nest is a rarity and there is reason to believe that the eggs are deposited in the deserted arboreal nests of other birds.

7I. Western Wiblét (Symphemia semipalmata inomata).

Once a common summer bird of our prairies, now greatly reduced in numbers. 
72. Bartramian Sindpriplik, Field T'lover, Lpland Plover, "Quaily" (Bartramia longicauda).

Once one of the most characteristic birels of all our upland prairies; but on account of its palatable flesh and tame and unsuspicious nature, together with the destruction of its natural habitat for purposes of agriculture, it has been reduced almost to the verge of extermination where it was once most abunclant. "The "passing" of the L pland Plover is much to be cleplored, and it is doubtful whether it can ever be reinstalled, even with the most rigid protection.

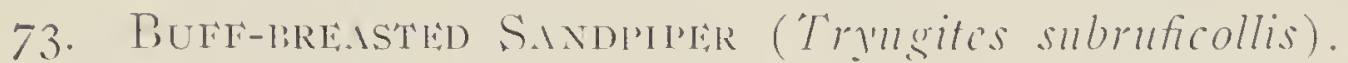

Occasionally encounterel during migration in compact flocks of many individuals, frecuenting the dry prairies in the neighborhood of lakes and watereourses.

74. SPOTTED S.MNDPIPER, "Tip up," "Tecter" (Actitis macularia).

A common summer resident, familiar to everyone as it feeds along the sandy shores of our lakes and streams.

75. LONG-BILLED CuRlin (Nmmenins longirostris).

The day of this large and conspicuous bird with its long curved bill has nearly passed in the settled portions of Minnesota. It was once a common summer resident on our prairies.

76. Hudsonman Curiaw ( 1 mmemins hudsomims).

A rare migrant if at all.

77. Eskimo CuRtew (Numenims borcalis).

Formerly an abundant migrant over the prairie regions of the interior, but now like the Passenger Pigeon, apparently a bird of the past. The explanation of its singular disappearance is not apparent.

78. BLACK-IBELLLII) P'IOVER (Squatarola squatarola).

Sonctimes common on upland prairies during migration.

79. Golden Plover (Charadrins dominicus).

A more common species than the last, occurring under similar conclitions.

So. Killdelir Provlir (Agialitis iocifera).

A common and familiar bird, its loud "Kill-dee, Kill-dec, Kill-dec" well-known to everyborly.

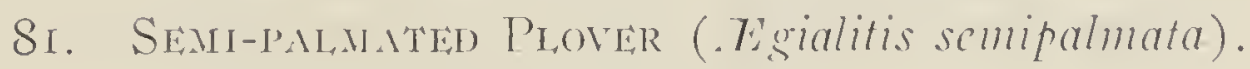

Occurs during migration. 
82. Beitid Piping Piover (Eg gialitis meloda circuncincta).

Like the last may be encountered during migration and possibly breeding.

83. Turnstone (Arenaria morinella).

May be looked for as a very rare migrant. F. H. Brackett reports seeing a "bunch of four" near Detroit in May, 1883.

84. Bob-Wmitr, Quail (Colinus airginianus).

Mr. D. W. Meeker, of Moorehead, states that this bird has of late years become a permanent resident in moderate numbers in the southern part of Becker County. This is probably the most northern locality for the state.

85. Canada Grouse, Spruce Partridge (Dendragapus canadensis).

Found in the evergreen forests of the county.

86. Ruirép Grouse, "Pheasant," "Partridge" (Bonasa umbellus togata).

A common bird of the forests, disappearing all too rapidly with the destruction of its haunts.

87. Prarie Hen, Pinnated Grouse, Prairie Chicken (Tympanuchus ancricanus).

This bird has extended its range northwestward until it is now found in almost all parts of Ninnesota, where the character of the surface is suited to its wants. It reached the western part of Minnesota twenty-five or thirty years ago.

88. Simarp-Tailed Grouse, "Prairie Chicken" (Pcdioccetes phasianellus campestris).

This was the original Prairie Chicken of the western part of our state. It is rather more frequently found among scattered timber and in brushland than the Pinnated Grouse.

89. P.issenger Pigeon, Wild Pigeon (Ectopistes migratorius).

Formerly an abundant bird throughout all the woodlands of the state, now probably entirely extinct everywhere. Brackett reports seeing near Detroit in Nay, I883, "a few small flocks," and adds that it was "very abundant a little later."

90. Mourning Dove, Carolina Dove (Zenaidura Macroura).

A common bird, often mistaken, when in flocks, for the last species, accounting for some of the reports of the latter bird being seen during late years. 
9r. 'Turkey Buzzard, 'Turkey Vulture (Cathartes aura).

Common.

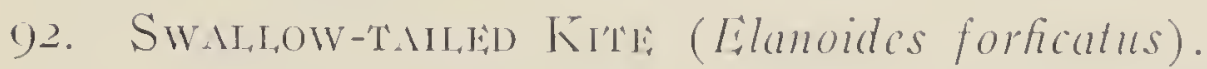

Oceurs as a summer resident in the forest-covered portion of the county. A single individual seen 1)y the writer at Elk Lake near the northeastern corner of liecker County in July, 1902.

93. Marsir HawK, Marsh Marrier (Circus hudsonius).

A common bird seen hunting low over the marshes and praries. Its food consists largely of meadow mice, frogs, snakes and large insects. It is therefore a useful bird and should not be thoughtlessly destroyed.

94. Sharp-shinneid Hawk (Accipiter a'clori).

'This trim little hawk is a stmmer resident and fairly common. It is rapid of flight and daring in pursuit of its prey. It is powerful for its size and destroys many birds and where opportunity offers does much damage among young poultry.

95. COOPER's HawK (Accipiter coopcrii).

Common. Resembling the last species, but decidedly larger. Often called "Hen Hawk." It works much havoc among wild birds and poultry.

96. American Gosmawk (Accipiter atricapillus).

Found chiefly in the winter time, but a few may breed in the heavy forests. A large, powerful bird that preys almost entirely upon rabbits, squirrels, grouse, ducks and poultry when the opportunity offers.

This hawk, together with the last two species and the Duck Hawk, to be mentioned later, are the outlaws among the diurnal birds of prey. 'They do far more harm in securing their chosen quarry, than can be condoned by the small amount of good they do in the destruction of injurious rodents and other animals. In the case of all the other hawks the balance is in their favor and they are of real bencfit to the farmer and are worthy of protection even if they do destroy an occasional domestic fowl.

97. Red-TALED Ilawk, "Hen Tawk," "Chicken Hawk" (Butio borcalis).

This is a common bird, forming the great bulk of the large hawks seen during the stmmer time. It is a valuable ally 
of the farmer, feeding as it does almost entirely upon gophers, squirrels, mice, grasshoppers and other insects with a few snakes, lizards and frogs, and, less frequently, wild birds and poultry. However, its few harmful deeds give it a bad name and it is relentlessly pursued and destroyed by every poultry raiser, when the real offender is usually one of the smaller species mentioned above.

A light colored variety of this bird, known as Krider's Hawk, and a dark western form, known as the Western Red Tail, may be looked for as of occasional occurrence.

98. Red-sinouidered Hawk (Butco lincatus).

A more southern species probably occurring occasionally in the summer time.

99. Swainson's Hawк, Grasshopper Hawk (Butco savainsonii). A common species. This bird feeds almost exclusively on striped gophers and mice, grasshoppers and crickets. At times it destroys large numbers of locusts and large grasshoppers, which it secures by beating low over the prairie and seizing them as they fly up from the ground. It is thus an eminently beneficial bird and should be recognized and carefully protected.

IOO. Broad-Winged Hawk (Butco playpterus).

A medium sized hawk that rarely kills birds and is distinctly of benefit to the agricultural interests. An abundant species.

IOI. AMERICAN ROUgh-LEGGED Hawk (Archibutco lagopus sanctijohannis).

A winter bird, feeding extensively upon mice and other small rodents.

The Ferruginous Rough-legged or Squirrel Hawk, a western species, may occasionally occur as a straggler.

IO2. Golden EAgli: (Aquila chy'sctos).

Chiefly a winter bird in the United States, but Prof. Cooke tells us that he has seen them in Becker County, presumably at White Earth Agency, as late as the first of June: which would seem to indicate that they formerly, if not at present, bred in the secluded parts of the county.

IO3. Batd Fagis (Haliactus leucocephalus).

Once rather common. Now restricted to a few pairs, nesting amid the wildest surroundings. A pair has nested 
for many years past in a large pine tree on the west shore of Elk Lake, but a short clistance north of the northeastern corner of Becker County. The writer inspected and photographed this eyrie, containing two young eaglets in July, 1902. The Bald Eagle makes bold to capture a few squirrels, rabbits, gophers, and an occasional birel; but for the most part secures its living by robbing the lisk llawk of its hard-earned prey. It is, also, not averse to carrion when hard pressed. A noble record for the birel selected as our national emblem!

IO4. GyrFalcon (Falco rusticolus).

This, or one of its two varieties, may be looked for as a rare accirlental winter visitant from the north.

ro5. Pramein Falcon (Falco mericamus).

A western species that may occur as a rare straggler in the prairie portion of the county.

106. Duck Hawk (Falco peregrimus anatum).

A beautiful, bold hawk of medium size. An occasional pair may be found nesting in tall timber about the larger bodies of water.

107. Pigen HawK (lialco colmmbarins).

A common little hawk of spirited habit, feeding chiefly on birds and insects and occasional small manmals.

I08. RichardSON'S MERLin (Falco richardsonii).

A western species that may occur as a rare visitor in the prairie portion of the county.

iog. Sparrow HawK (Falco sparicrius).

An abundant and beantiful little hawk to be seen sitting motionless on the top of a stub or fence post, or poised on rapidly-beating wings, as it looks for the mouse or grasshopper in the grass below. A very useful bird that has been all too greatly recluced in numbers of late years. Nests in holes in trees.

I IO. Ospriy, Fisn H. WK (Pandion halicetus carolinensis).

A few pairs nest about the larger bodies of water. They were to be seen daily about Lake Itasca in the summer of rgo2, securing their prey by bold dashes into the water. often from a consiclerable height. 'They seize the fish in their talons and bear it off to be devoured at some con- 
venient resting place when not clespoiled of their quarry by the watchful Bald Eagle.

I I I. LONG-EARED OWh (Asio wilsomianus).

A common inhabitant of tamarack and white cedar sivamps.

Migrates south in the winter.

I 2. ShorT-EARED OWL (Asio accipitrinus).

Common. A bird of the marsh and prairie, rarely, if ever,

found in woodland. Summer resident only.

I I3. BiRRED OWL (Syrnium nebulosum).

A frequent species in heavy timber.

I 4. Great Gray Owh (Scotiaptex cinerea).

Occasionally found in the winter time in the heavy forest.

i 5. Richardson's Owi, (Nyctala tengmalmi richardsoni).

A small owl, occurring occasionally in winter.

I 6. SAW-WHET OWI, (Nyctala acadica).

The smallest of our owls. A not uncommon permanent resident, nesting in deserted woodpecker holes.

i 7. Screich Owr, (Megascops asio).

This is the common little owl that comes so fearlessly about farms, hunting for mice among the out-buildings and about the grain stacks. Remains through the winter.

i 8. Great Horned Owh, Cat Owh (Bubo airginianus).

The commonest large owl. Found chiefly in heavy woods. This bird is large and powerful and very destructive to mammals and birds of many species. It kills a large number of rabbits and works havoc among the Ruffed grouse during the late fall and winter season, when other food is not as easily obtained.

The owls are, for the most part, beneficial to agricultural interests, as they destroy, in their nocturnal prowlings, an immense number of mice, other small injurious mammals, and insects, some of them of the most damaging varieties. The Great Horned and the Great Gray are the only two species an inventory of whose food would show the balance to be seriously against them. 'The farmer, who kills the smaller owls, is thoughtlessly destroying most valuable allies in the constant warfare which it is necessary to wage against his natural enemies.

A light variety of the Great Horned Owl is known as the Arctic Horned Owl. 
i i9. Snowy Owr (Nyeteanyetea.)

$\Lambda$ winter visitant, sometines appearing in consirlerable numbers, usually in open country. It is a powerful owl, destructive to birds, mammals and fish, but its numbers are usually so limited that it is not a (listurbing element of much importance.

120. AmliRican IIAWK OWh. (Surnia ulula caparoch).

A rather common winter visitant throughout the forests of northern Minnesota and a few probably remain to breed. This owl is suid often to hunt its prey, hawk-like, in the daytime.

The popular idea that owls are able to see but very imperfectly in the daytime is not entirely correct, for most, if not all, varieties can see well enough to get about with perfect ease when forced to move, and several other species besides the ITawk Owl occasionally hunt by day.

I 2 I. Burrowing OwL (Speotyto cunicularia hypogaa).

A bird of the prairie dog towns further west, occasionally found in western Minnesola inhabiting deserted badger and fox dens.

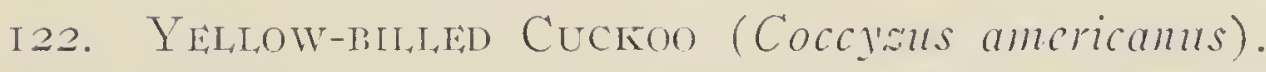

I 23. Biack-BILled CUCKOO (Coccyans crythrophthalmus).

The cuckoos are rather common but shy birds and little seen as they inhabit the thick underbrush. Their loud, rattling call is, however, well known; and the belief, that they utter it usually just preceding storms, has given to them the common name of "Rain Crow." They are about the only birds that will eat, in any considerable numbers, the hairy caterpillars which are often such a pest; and they are therefore, among our most beneficial birds. Unlike the Enropean Cuckoo they build their own nests and rear their own goung.

24. Beited Kinglisher (Ceryle alcyon).

Common about all the lakes and streams.

I 25. HARY WoODPECKER (Dryobates aillosus).

Common in heavy timber and wooded swamp-land.

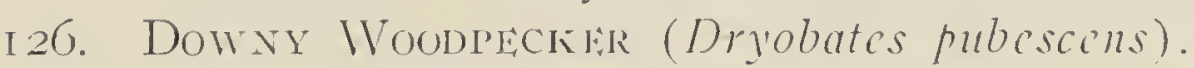

Abundant everywhere in woorlland.

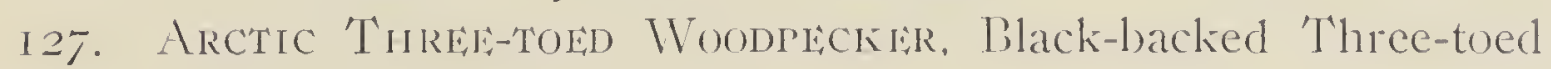
Woodpecker (Picoides).

A common permanent resident in the evergreen forests. 
i28. American Threk-Toed Woodpecker, "Ladder-back" (Picoides americanus).

An uncommon bird. Breeding at Lake Itasca in 1902.

I29. Yeilow-Beidied Sapsucker (Sphyrapicus ratius).

A common summer resident. This bird from its habit of piercing the bark to secure the sap, does much injury to many varieties of trees, including cultivated fruit and ornamental species. It is therefore to be regarded in the light of a pest-the only outlaw anong the woodpeckers, which are, as a family, among the most useful of all our birds.

I3o. Pileated Woodpecker, Logcock, Cock-of-the-Woods, (Ceophlocus pilcatus abicticola).

This, the largest of our woodpeckers, is still rather common in the primitive forests. It is a most useful bird and should never be ruthlessly destroyed simply because it is an object of curiosity, as is so frequently the case.

I3I. RED-HEADED WOODPECKER (Mclanerpes erythrocephalus).

Common in open woodland and about habitations.

132. Fincker, "High Hole," "Yellow Hammer," "Golden-winged Woodpecker (Colaptes auratus luteus).

A familiar bird known to everyone. More terrestrial in habit than the other woodpeckers, feeding extensively on ants which it secures by thrusting its long, sticky togue into their burrows.

I33. Whip-poon-will (Antrostomus vociferus).

Present. Brackett says, "Heard one on May 6, I883, near Detroit."

I34. Night'-HAwк, Bull bat (Chordeiles virginianus).

A common and well-known bird. The birds found on the prairie and in open country are light-colored and are known as Sennett's Night-hawk.

I35. Chimney Swifr', Chimney "Swallow" (Chatura pelagica).

Abundant. Formerly bred in hollow trees.

i36. Ruby-throateid Hummingbird (Trochilus colubris).

Common.

I37. Kingbird (Tyrammis tyrammus).

Abundant.

I38. Artansas KingBird (Tyrammus verticalis).

A western species found rather commonly in the tree claims and groves along the borders of the prairies. 


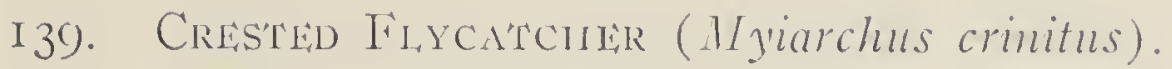

Frequent in heavy timber about lakes and along waterconrses. Builds its nest in a cavity in a tree. This is the Flycatcher that almost invariably places a cast-off snakeskin in its nest.

I40. Pнøве, House Pewee (Sayomis phrobc).

A familiar bird, nesting about out-buildings and under bridges.

I4I. OIIVE-SIDED FILCATCIISR (Contopus borealis).

A summer resident in heary woodland. Brackett says: "Saw several near Detroit in I883."

I42. WOOD PEWEir (Contopus a irens).

A common bird in all woodland.

443. YELLOW-BELLIED FLYCATCIER (Empidonar flariventris).

A common migrant, and probably a few breed in damp woodland.

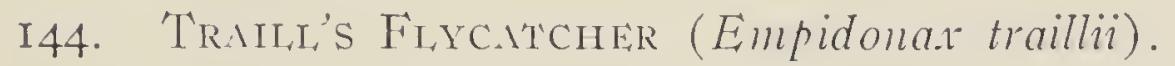

Common, frequenting chiefly willow groves and low-lying brush land. Probably, in part, at least, the variety known as the Alder Flycatcher.

I45. LEAST FLYCATCHER, Chebec (Empidonar minimus).

The most common member of the family in all woodland.

I46. PRAIRIE HORNED LARK, Shore Lark (Otocoris alpestris praticola).

A common bird everywhere in open country. Retreats southward in winter and returns at the very earliest suggestion of spring.

A larger variety known as Hoyt's Horned Lark, which breeds in British America, may be looked for as a late fall and early spring visitant.

147. Bius JAY (Cyanocitta cristata).

Common, and familiar to all.

I48. CANADA JaY, "Moose Bird," "Camp Robber," "Whisky Jack" (Perisorens canadensis).

Common, noticed chiefly in the winter time as it then forages about lumber camps and forest dwellings. In the early spring it retreats to nest in the most inaccessible spruce and white cedar swanips. 
I49. NoRTIISR R.WHA (Corcus corar principalis).

Occurs chiefly as a late fall, winter and early spring visitant from the north, feeding about camps and along the shores of lakes and rivers.

i5O. Anerican Crow (Coraus americanus).

Very common.

Clarke's Nutcracker, a western bird, has been taken as a rare straggler in western Minnesota and may be looked for in Becker County.

I5I. Bobornn, Reed Bird, Rice Bird (Dolichony oryizorus).

An abundant bird in all prairie meadows. Called Rice Bird in the south where it is very destructive in the rice fields; in the north a harmless or beneficial bird.

I52. Cow Bird (Molothrus ater).

Common. A parasitic bird, never building a nest of its own, the eggs being deposited in the nests of other birds, usually a species smaller than the cow bird. The roung are cared for by the foster parents.

I53. YELLOW-IEADED BLACKBIRD (Xanthocephalus ranthocephalus).

Abundant in all quill-reed and cat-tail swamps. A powerful bird, doing much harm to corn, oats and wheat but also feeding extensively upon grasshoppers and locusts.

I 54. RED-WINGED BiackiriRd (Agclaius phaniceus.)

An abundant and destructive bird although the injury it does to grain is somewhat compensated for by the numerous number of injurious insects and weed seeds which it consumes.

A variety known as the Thick-billed Redwing occurs as a migrant in late fall and early spring.

155. Western MeAdow LaRK (Sturnella magna neglecta).

Abundant. A valuable bird to the farmer.

156. Orcitard Oriole (Icterus spurius).

Brackett says, "Quite common" at Detroit in May, I883, but this is so near the northern limit of its distribution that one would expect it to be of infrequent occurrence.

I57. Baltimore Oriole, "Hangnest," "Golden Robin," "Golden Oriole" (Ictcrus galbula).

Very common. 
158. Rustr biackindRd (Scolccophagus carolinus).

A common migrant spring and fall, breeding in the far north. Occurs in large, noisy flocks.

159. BREWER'S B1.ACKRIRD (Scolecophasus cyanocephalus).

Similar to the last in appearance. I summer resiclent. breeding in colonies in poplar groves and other small timber.

IGO. Bronzed Grackis, Crow Blackbird (Quisculus quiscula (cucus).

Common, breeding. Most noticeable in the late summer and fall when they congregate in loose flocks, feeding about farm-yards, ficlds and lawns, destroying a large number of injurious insects and grubs that compensate in some measure for the injury that they do to the farmers' crops.

ín. Eitening Grosbente (Coccothraustes a'espertimus).

A winter visitant, appearing in small flocks. 'Tame and unsuspicious in habits. Feeds largely on fruit of the boxelder, maple and hackberry.

I62. PINE GROSBEAK (Pinicola cmucleator).

Also a winter visitant. Fond of the fruit of the sumac and high-bush cranberry.

i63. Purpis Finci (Carpodacus purpurcus).

Chiefly to be seen in flocks, spring and fall, but a few breed in the evergreen forests.

i64. Americin Crossmila (Lomia curitrostra minor).

A permanent resident throughout northern Minnesota.

165. Whit:-Winged Crossine (Lovia lencoptera).

Occurrence the same as the last but usually not so plentiful.

I66. REDPol. (Acanthis linaria).

A visitant from the north, occurring in flocks often of considerable size.

Two other varieties, the Iloary and the Greater, may be looker for as occasional associates of the common Redpoll.

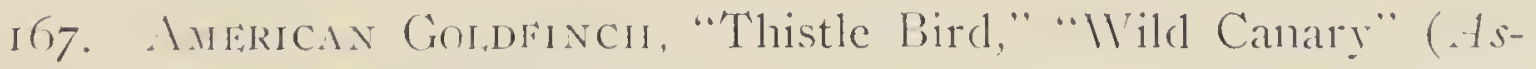
tragalimus tristis).

Common. Nesting late in summer.

i68. PINF: Siskin (Spinus pimus).

Much less common than the last, chiefly seen spring and 
fall, but a few may nest in the pine forests of the northeastern corner of the county.

i69. English Sparrow (Passer domesticus).

Introduced into the United States in 1850, this bird has spread until it is now a resident in almost every state and territory of the Union and in most parts of British America.

I7o. SNOWFlake (Passerina nivalis).

A winter visitant from the north, occurring in large flocks in open country. Chiefly noticeable in the late fall and early spring.

I7t. LAPLAND LONGSPUR (Calcarius lapponicus).

Like the last.

I72. Smith's Longspur (Calcarius pictus).

May occur in company with the last species.

I73. ChestNut-COLLARED Longspur (Calcarius ornatus).

A common summer bird on the higher prairies.

I74. McCown's Longspur (Rhynchophanes mccormiii).

To be looked for as a breeding bird, often in wheat-fields among the growing grain. Breeds in Pipestone and Lac qui Parle Counties.

I75. Vesper Sparrow, Grass Finch, Bay-winged Bunting (Poccetes gramineus).

A common roadside bird.

I76. SavanNa Sparrow (Ammodramus sandrichensis sazamma). Common in meadows.

I77. BaIRD's Sparrow (Ammodramus bairdii).

A prairie bird, common in the same situations as the last species.

i78. Grasshopper Sparrow, Yellow-winged Sparrow (Ammodramus sazannarum passerimus).

A common bird of upland prairie and grass fields.

i79. Henslow's Spakrow (Ammodramus hensloziii).

This tiny bird, almost mouse-like in habit, is not uncommon among rank grass, in dry meadows or upland fields.

I80. LECONTE's SPARROW (Ammodramus leconteii).

Common in the marshes and meadows about prairie sloughs.

181. Nelson's Siarrow, Nelson's Sharp-tailed Finch (Ammodramus nelsoni).

Firequents prairie marshes. Breeding. 
I82. Lark Sparrow, Lark linch (Chondestes grammacus).

A bird found chiefly in semi-prairie country. Usually comminn.

I83. Harris' Sparkow (Zonotrichia qucrula).

Migrant, spring and fall. Usually abundant in the latter season.

I84. White-CROWNed Sparrow (Zonotrichia leucophrys).

Like the last but less common.

What is known as Gambel's or the Intermediate Sparrow, a western variety of this species, occurs regularly during the migrations, often in considerable numbers.

I85. WhITH-THROATED SPARROW (Zonotrichia albicollis).

Common summer resident, breeding throughout the evergreen portion of the county.

is6. Treis Sparrow (Spiaclla monticola).

An abundant migrant spring and fall.

i87. Chipping Sparrow, "Chippy," Hair-bird (Spizclla socialis).

Common, often breeding familiarly about houses and in towns.

i88. Clay-Coloreid Sparrow (Spiaclla pallida).

Abundant.

i89. Slate-Colored Junco, Snow Bird (Jullco hyemalis).

An abundant summer bird throughout the evergreen region. Elsewhere migrant spring and fall.

An occasional example of the western variety known as the Oregon Junco, may be found among the migrating flocks.

igo. Song Sparrow (Melospiza melodia).

Common summer resident.

i9i. Lincoln's Sparrow (Mclospiza lincolnii).

Found chiefly in the evergreen forests. Probably breeds, but apparently not common.

192. Sinamp Sparrow (Mclospiza georgiana).

Common. A bird of wet swamps, especially where grown up in bushes.

193. Fox Sparrow (Passcrella iliaca).

A common migrant spring and fall.

I94. TowneE, Chewink, "Ground Robin" (Pipilo crythrophthalmuls).

A common bird in woodlands. 
195. Rosm-1irmastem Grosman (Zamclodia Indoriciana).

A common summer resident.

196. Indigo Bunting (Cyamospiza cyanea).

Infrequent, probably reaching the northern limit of its distribution in the open woodland of the southern part of Becker County. Prof. W. IV. Cooke states that he did not see it during a three years' residence at White Earth Agency; but Mr. B. T. Gault reported seeing several, May 27th. I893, in going from Detroit to Lake Licla. At the latter place several were encountered June 15 th of the same year in a brushy pasture. The writer did not see it at Lake Itasca, but it occurs at I,eech Lake.

197. Dickcissit, Black-throated Bunting (Spisa americana).

A summer resident, frequenting chiefly grass, clover and grain fields, where it nests in late June and July. Becker County is near the northern limit of its range but it has been found nesting in Polk County, still further north and it has been reported from Marshall County.

198. Lariz Bunting, White-winged Blackbird (Calamospiza melanocorys).

A bird of the western plains found on the upland prairies of western Minnesota, often commonly.

I99. Scarlet TANager (Piranga crythramelas).

Found as a summer resident in open woodland.

200. Purple: Martin (Progne subis).

Common about settlements.

20I. Chifie Swallow (Petrochelidon lunifrons).

Common, breeding under the eaves of buildings.

202. BaRn Swaldow (Hirundo crythrogastra).

Common.

203. Tree Swallow, White-bellied Swallow (Tachyniceta bicolor).

Common. Nesting in holes in trees and stumps.

204. Bane Swallow (Riparia riparia).

Frequent, nesting in colonies in holes in banks along rivers and lakes.

205. Rougi-Winged Swaldow (Stelgidoptery.r scripennis).

Similar to the last but less sociable.

206. Bohemian IVaxwing (Ampelis garmlus).

A winter visitor from the north, coming often in considerable flocks, but very irregularly. 
207. Cindr lines, Cherry Bird, Ceclar Waxwing (Ampelis cedrorullin).

An abundant summer resident.

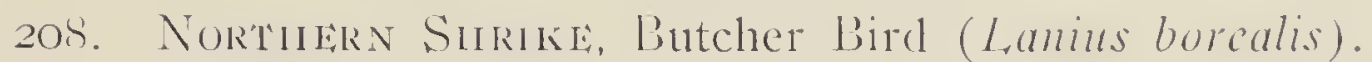

A spring and fall visitor, but probably not found diring the winter except in unusually mild seasons.

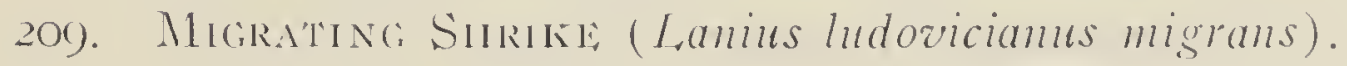

A summer resident.

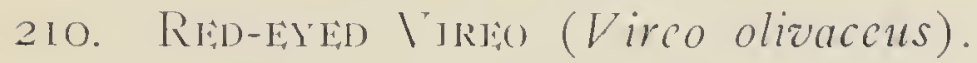

Common everywhere in woodland.

2i i. Philadilinia Vireo (Vireo philadelphicus).

An uncommon migrant, possibly breeds.

2I2. WARBLing VIRJO (Tirco gitius).

Common.

2I3. YELLOW-TIIROATED VIREO (Vireo flazifrons).

A summer resident, less common than either the Red-eyed or Warbling.

2i 4. Br,UE-HEADED VIREO, Solitary Vireo (Virco solitarims).

Breeds rather commonly in the evergreen forests in the northeastern corner of the county, elsewhere a migrant.

2I5. Bhack AND White Warbler (Mniotilta z'aria).

A summer resident throughout the wooded portion of the county.

2i6. Golden-Winged Warbler (Helminthophila chrysoptera).

A summer resident in bushy woods especially near tamarack swamps.

217. Nasinvile Warbeer (Hclminthophila rubricapilla).

A common summer resident in the tamarack and white ceclar swamps.

2i8. OR.NGE-CROWNED W.MBLar (Hclminthophila celata).

A common spring and fall migrant.

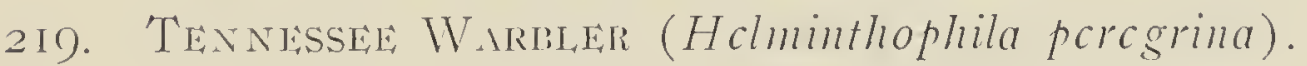

A very abundant migrant spring and fall.

220. PARULA WARBLER (Compsothlypis amcricana).

A rather common summer resident in the heavy timber.

221. CAPE MAY WARBdiR (Dendroica tigrima).

A spring and fall migrant.

222. YELLOW WARBIER (Dendroica astiza).

An abundant summer resident. 
223. Blace-Throated Bl,ue Warblekr (Dendroica comlescens). An uncommon migrant.

224. MyrTleE WARblek, Yellow-rumped Warbler (Dendroica coronata).

An abundant spring and fall migrant. A few pairs probably breed in the Lake Itasca region.

225. Magnol,ia Warbletr (Dendroica maculosa).

A common migrant, breeding in limited numbers in the evergreen forest.

226. Chestinut-Sideid Warbletr (Dendroica pemisylianica.)

A common summer resident.

227. BAY-breasted WARbiek (Dendroica castanea).

An uncommon migrant.

228. Brack-POL, Warbi,ER (Dendroica striata).

A common migrant.

229. Blackburian Warbier (Dendroica blackburmice).

Breeds rather commonly in the heavy forests of the county.

23o. Black-throated Green Warbler (Dendroica virchs).

A bird of the heavy forest, living almost exclusively in the tree tops.

23r. Pine Warbleir (Dendroica rigorsii).

An abundant summer resident in all "Jack pine" timber.

232. Palm Warbleir (Dendroica palmarum).

A common migrant.

233. Oven BIRd (Sciurus aurocapillus).

Common everywhere in woodlands.

234. Grinneld's WaterR-Thrusi (Seiurus noveboracensis notabilis).

Summer resident in low-lying woodlands. Common along the banks of lakes and streams during migration.

235. Connecticut Warble (Geothlypis agilis).

To be looked for as a rare migrant.

236. Mourning Warbier (Geothlypis philadelphia).

A common summer resident, breeding in old "burns" in the pine forest.

237. Maryland Yeidiow-'THRon't (Geothlypis trichas brachidactyla).

A common summer bird in all bushy meadows.

238. Wilson's Warblerr (Wilsonia pusilla).

A spring and fall migrant. 
239. Canadan Warbezr (Wilsonia canadensis).

Chiefly as a migrant, but a few breed about the white cedar swamps.

240. AnjRican Rbosiart (Setophaga ruticilla).

A common summer resident.

24I. AnErican Pifí (Anthus pemsylianicus).

Spring and fall migrant, seen usually in open country or along the beaches of the larger lakes.

242. Sprigués Pipit (Anthus spragucii).

A western species occurring on the prairies of the western portions of the county. This bird soars and sings high in the air like the English skylark and our own horned lark.

243. CAT Biro (Galcoscoptes carolincusis).

Common summer resident.

244. Brown Thrasher (Tonostoma mufum).

Quite common in the more open wooded portions of the county.

245. WESTERN HOUSE WREN (Troglodytes adon aztecus).

A common and well known little bird.

246. WINTER WREN (Olbiorchilus hicmalis).

A summer resident, breeding in the heavy forest, but not commonly. More frequent as a migrant. Not found in the winter as its name implies.

247. Short-billed MARsh Wren (Cistothorus stellaris).

A common bird in meadows and marshes.

248. LONG-BILLED MARSI WREN (Cistothorus palustris).

A commoner bird than the last, found in wetter marshes.

249. BROWN CREEPER (Certhia familiaris americana).

This tiny little bird is common in all woodland, migrating south in the winter.

250. WhITE-BREASTED Nu'HATCH (Sitta carolinchsis).

A common permanent resident in all woodland.

25I. REI-IREASTED NUTIATCII (Sitta canadensis).

A summer resident, migrating southward for the winter.

252. CHICKADEE (Parus atricapillus).

A permanent resident. Common.

253. Hudonian Cinckiditis (Parus hudsonicus).

A northern species to be looked for as a winter visitant, possibly nesting, as it does regularly in the northeastern part of Minnesota. 
254. GOLden-CROWNED Kinglit (Regulus satrapa).

A common spring and fall migrant.

255. RuBy-CROWNAD KIngLET (Regulus calcudula).

An early spring and late fall migrant, usually in consiclerable numbers.

256. Wood Tmrusir (Hylociclila mustclina).

A summer resident, its beautiful song heard in almost all woodland.

257. Wilson's 'Tinrusir, Veery (Hylocichla fuscescens).

A common summer resident.

258. GRAY-CHEEKED TIIRUSi (Hylocichla alicic).

A spring and fall migrant.

259. Orive-backed 'Thrusir, Swainson's Thrush (Hylocichla ustulata szoainsonii).

A summer resident in the evergreen forests.

260. Hermit Trrrush (Hylocichla guttata pallasii).

An abundant summer resident throughout the coniferous forests. Its wonderful song could be heard coming from all directions until far into the twilight every evening at Lake Itasca during June and July, rgo2.

26r. American Robin (Mcrula migratoria).

An abundant summer resident, often seen migrating in considerable flocks.

262. Blue-BIRd (Sialia sialis).

A common and familiar bird, nesting not only in boxes about habitations, but very commonly in holes in tree stubs standing in open places in the forest.

\section{Disappearing Birds and Game Birds.}

BY D. IV. MEEKER.

Many of the birds that were common in Becker Connty in early days have become rare and some of them almost extinct in this locality. This is especially true of the swan, pelican, whooping crane, sandhill crane, blue heron, cormorant, wood duck, wild pigeon, woodcock and bald eagle.

The last named, the emblem of the nation, formerly nested in the county; and the last nest, of which there is a record, was in a large tree which stood on an island in Cotton Lake. This 
tree blew down about five years ago and the eagles have found a new nesting place more remote from civilization.

In 1897 a whooping crane was found cleat in 'lown Iake. south of Frazee. The bird harl been shot and had probably flown some distance before his wouncls proved fatal. Albert I ligbee, in the history of Walworth, also mentions the killing of one in that tornship in the early eighties.

Cormorants and pelicans formerly nested in Becker Connty and the fact that two lakes were named after these birds is due to this fact. The cormorants formerly nester on the islands in the lake of that name, in the southwestern part of the connty, but were forced to vacate by the settlers.

There were several colonies of blue heron in the county, but now the nests are widely scattered. During the summers of I885 to 1889 the Indians cut down about thirty pine trees each year on the shores of Rice Lake, north of Height of Land Iake, in order to get the young birds for food.

'The wild pigeon, which at one time was found everywhere in North America, from Mexico to Hudson's Bay and from the Atlantic Ocean to the Rocky Mountains, has entirely disappeared. 'These birds nested in Becker County and as far north as Hudson's Bay. Until the seventies the wild pigeon was very plentiful and countless thousands of them were killed in this locality. 'The last one seen in Becker County, of which there is a record, was observed by Mr. Wilcox in I888. This bird was crippled and remained through the summer of that year in a little grove of pine trees on the banks of the Otter Tail River about eight miles north of Frazee.

Woodcock never were plentiful in Becker County and for many years have been very rare. 'This is one of the game birds that is rapidly disappearing and will soon be referred to only in the past tense.

The finest of all our ducks, the graceful, beautifully plumaged wood dick is another favorite that is becoming rarer each year. This bird formerly nested in holes in trees near the lakes and streams of Becker County and some of them still breed in remote sections of the county. Old settlers recall seeing the mother bird carrying her young, one by one, in her bill to the water from the nest in the tree.

Other birds that are practically extinct in this locality, are the avocets, curlews and godwits. 
The demand for game birds for the eastern markets well nigh caused the extermination of the ruffed, pinnated and sharp-tailed grouse by the market hunters, aided and abetted by traders in the villages. Since the sale of all game has been prohibited in Minnein the woods. Limiting the open season, also the number that may be killed in a day, are factors that aid their protection. It will be necessary, however, to enact and cuforce more stringent laws, else these birds will, like the buffalo, soon be exterminated.

The ruffed grouse, the king of game birds of Minnesota, is found in all the timbered parts of Becker County. This splendid bird is also called "partridge" and "pheasant," because of their resemblance to their European relatives. Dr. Cones says, "The bird itself is unmistakable; no other species has the conspicuous ruffle of lengthened, broad, soft, silky (purple-black) feathers on the neck." No one who has heard the whirr of the ruffed grouse, when taking wing, could mistake this peculiar, startling sound for any other. Nor can one mistake the drumming sound made by the male bird, by rapidly vibrating his wings, while standing on a log or stump. The home of the ruffed grouse is in the woodlands - in the summer they are found near openings and around berry patches, but as the leaves fall and winter approaches they seek the cover of heavy timber and wooded swamplands. They pair in the early spring; nest upon the ground in the shelter of brush, a fallen $\log$ or in a hollow between the roots of a tree. The number of eggs varies from ten to sixteen; and the newly hatched chicks quickly hide under leaves or brush when the mother bird sounds the note of alarm. She will pretend to be wounded in order to lead an intruder from the vicinity of her brood, and will attack one who continues to approach after the little brown shadows have disappeared.

No game bird is more difficult to shoot. Their colors blend so completely with their surroundings that it is difficult to distinguish them until they are awing-then the hunter often has only a glimpse of a whirring, brown body, darting to the cover of nearby brush or timber. The flesh is white, extremely delicate, and highly prized.

Comparatively little is known of the Canada grouse, or, as it is commonly named, the "spruce grouse" or "spruce hen." This bird was also called the "fool hen" because it had not learned to fear man. With the approach of civilization it has retires to 
the dense forests and dark swamps where it is rarely seen. In summer it feeds upon berries, the buds and leaves of plants and shrubs and insects. In the winter its food is mainly the buds and leaves of pine and other coniferous trees.

The sharp-tailed grouse was the original "prairic chicken" of the west and was plentiful in Becker County, especially in the western part where prairie and woodland meet. 'I'hey are about the same size as the pinnated grouse, and the distinguishing marks are: the pointed tail; lighter colored plumage, especially on the breast and lower part of the body; heavier feathering of the legs and extending well upon the feet. Its home is in the rolling country where there is brush or stunted growth of timber. A favorite bird with sportsmen, as they lie close for the dog: usually rise singly, and when flushed will fly but a short distance. In summer they feed upon berries and insects, in the winter upon buds of brush and trees.

The pinnated grouse or prairie chicken was driven west by the advance of civilization and for many years has been found upon the prairies and in the openings in the timber of Becker County. The pairing season begins with the breaking up of winter, when the booming of the male bird sounds like the beating of a muffed drum. This sound is made by inflating the orangecolored receptacles at either side of the neck, and issuing the call for the female, which is at the same time a challenge to other males. Their nest is a crude affair of grass on the sod or in the stubble. The number of eggs laid varies from eight to sixteen and the female has entire charge of incubation and the care of the young. Coveys remain together until late in the fall when the birds "bunch," the flocks often numbering from one to two hundred. Early in the fall the birds lie well to the dogs and, unless scattered, nearly all of the covey will take wing at the same time, the mother rising slightly in advance of her young. As the season advances the birds become wilder and, when disturbed, fly a long distance. They feed upon small grain and seeds, which are invariably picked from the ground, and are fond of grasshoppers and other insects. In the winter they roost in trees, feed upon buds, around straw stacks and in cornfields and weed patches. The flesh is dark, of a gamey flavor and is highly prized. Distinguishing marks are, the short rounded tail and the little wings of narrow. straight, pointerl feathers at either sille of the neck. 
Quail have several times reached the southern townships of Becker County where several bevys were hatched in Igo6. These birds resemble young ruffed grouse with abbreviated tails. They are very prolific, the female laying from twelve to twenty eggs. Both parents aid in the process of incubation and in the care of the young. They feed mainly upon seeds and insects and from an economic standpoint are considered the most valuable of all birds. The call of this beautiful bird resembles the name by which it is known in some localities--"Bob White." Quail are difficult to shoot on account of their extremely rapid flight. They live through a winter when the snowfall is light; but when the snow is heavy they find it difficult to procure food. As they roost upon the ground, huddled together in some sheltered spot, they are often smothered by drifting snow.

Many varieties of wild ducks, besides the wood duck, still nest in the unsettled parts of the county. During the seasons of migration, in the spring and fall, the ducks tarry with us until they leave, on the northern journey for their breeding grounds; and in the fall for their winter homes. The lakes and marshes of Becker County, where wild rice and celery thrive, are favorite haunts for these birds and there the hunters seek their quarry.

English and other snipe are numerous about the open marshes during the spring and fall. Some varieties still breed in the county.

Lpland plover still breed extensively on the prairies and meadows of Becker County and leave, late in the summer, for southern climes. Late in the fall the golden plover stop over a few days before proceeding on their journey to the grassy ranges of Texas and Northern Mexico. 




\section{Gaylord Bros.}

Makers

Syracuse, N Y.

PAT. JAN. 21, 1908

8.

2 


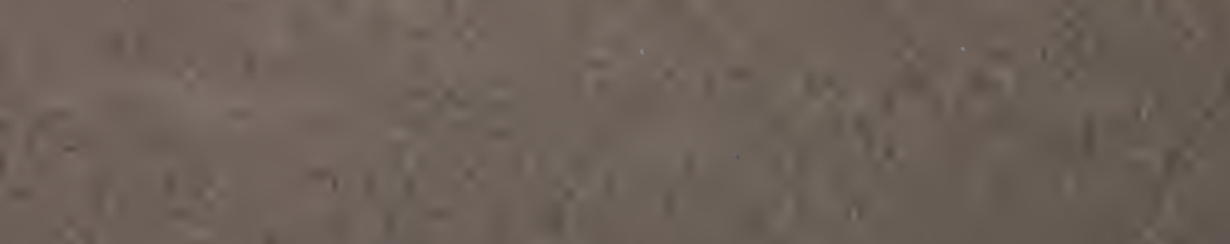

